\title{
Gross morphometrical postnatal developmental studies on spleen of Chotanagpuri sheep (Capra ovis)
}

\author{
S. MEHTA, S.K. DESHMUKH ${ }^{1}$, A.P. MINJ ${ }^{1}$, K. KUMAR ${ }^{1}$, L. KUMARI ${ }^{1}$ AND \\ J.K. SHAHI ${ }^{1}$
}

\begin{abstract}
This study involved morphologic and morphometric postnatal development on thirty spleens of the Chotanagpuri sheep. The spleen was collected and biometrical parameters were recorded. The spleen was found high in the abdominal cavity adjacent to the vertebral column in the region of $10-13^{\text {th }}$ ribs in all age group. The colour of spleen varied with advancement of age which was creamish in early age and gradually became reddish brown. The shape of the spleen was roughly triangular in all age groups. The mean weight, maximum length, maximum width, length of dorsal, anterior and posterior borders and thickness of dorsal border at anterior, middle and posterior ends, thickness of anterior border at dorsal and middle ends, thickness of posterior border at dorsal end of spleen and distance of hilus from dorsoanterior and ventro-anterior angle significantly increased among different groups of sheep with advancement of age. However, there was no significant difference in thickness of anterior border at ventral end, thickness of posterior border at middle and ventral ends.
\end{abstract}

Key words : Gross morphology, Biometry, Postnatal development, Spleen, Chotanagpuri sheep

How to cite this paper : Mehta, S., Deshmukh, S.K., Minj, A.P., Kumar, K., Kumari, L. and Shahi, J.K. (2016). Gross morphometrical postnatal developmental studies on spleen of Chotanagpuri sheep (Capra ovis). Vet. Sci. Res. J., 7(2) : 83-86, DOI : 10.15740/HAS/VSRJ/7.2/83-86.

Paper History : Received : 28.05.2016; Revised : 19.08.2016; Accepted : 06.09.2016 